\title{
Properties of Eccentric Elliptical Gearing
}

\section{Silvia Medvecká-Beňová}

Technical University of Košice, Faculty of Mechanical Engineering, Department of Construction, Automotive and Transport Engineering, Letná 9 Street, Košice, Slovakia

\begin{abstract}
Gearing was designed to meet continuous change of gear ratio during one rotation. The gearing consists of two identical gears and the basic shape of the gear wheel is formed by an ellipse. Wheels are designed for only one direction of rotation and the center of rotation is one of the foci of ellipse. Such designed and manufactured elliptical gearing was subjected to the tests and meets all the requirements that were imposed on the gear. This paper deals with properties of gear with variable transmission. Properties of this gearing are different from the properties of standard circular gears.
\end{abstract}

\section{Introduction}

We face the ever increasing demands on machine parameters nowadays. This request is expressed by their required loads' growth and dynamics calling for the continuous improvement of various machine parts because of the demanded load capacity, accuracy, durability and safety of the machinery. Therefore, one has to consider the dynamic properties of processes taking place in them.

The internal dynamics of the teeth is one of the most common gearing problems [3]. Detailed knowledge of meshing conditions is a prerequisite for studying kinematic conditions in gearings, as well as the strength calculation of gearing. The article deals with the problems of kinematic properties of non-circular gear. The problem is solved for the elliptical, eccentric gear with a continuously variable gear ratio within the range from 0.5 through 1 to 2 .

\section{Geometric Properties of Eccentric Elliptical Gearing}

Sponsoring of this work by the private sector called for development of the gear model using the CAD system for the variable transmission in the range $\mathrm{u}=0.5$ to 2.0 , with the number of teeth $\mathrm{z}_{1}=\mathrm{z}_{2}=24$ and gearing module $\mathrm{m}_{\mathrm{n}}=3.75 \mathrm{~mm}$, the distance $\mathrm{a}=90 \mathrm{~mm}$ and for one direction of rotation.

Given that each gear must satisfy the conditions of proper meshing, it was necessary to determine the geometric shape of the wheels. The gearing is designed such that the pitch curve is

Autor korespondujący:

Silvia Medvecká-Beňová, silvia.medvecka@tuke.sk

Artykuł recenzowany

nadesłany 12.04.2016 r., przyjęty do druku 27.04.2016 r.

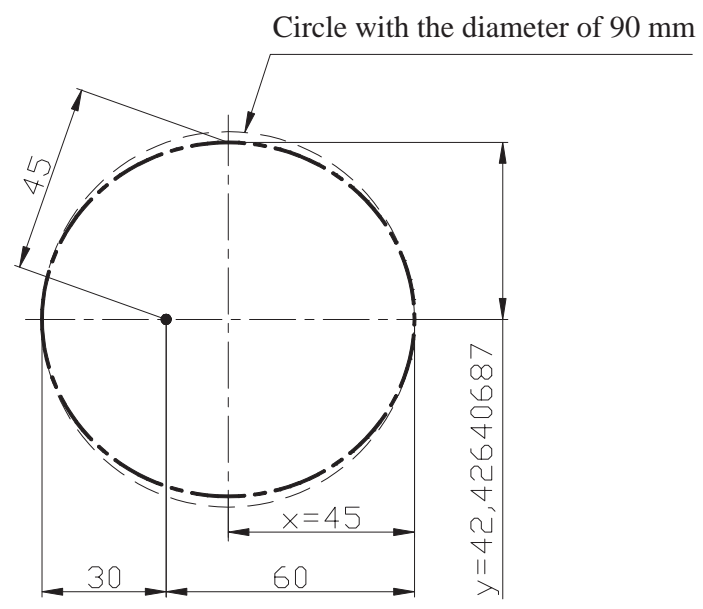

Fig. 1. Dimensions of a pitch ellipse Rys. 1. Wymiary elipsy tocznej

composed of an ellipse formed with the basic parameters shown in Fig. 1. The geometric centre of the gear is not the centre of wheel's rotation. The center of gear's rotation is in the focus point of the ellipse.

The pitch ellipse has a large half-axis $\mathrm{x}=45 \mathrm{~mm}$, which is a half of the axial distance. The second half-axis is determined by the distance from the focus point $45 \mathrm{~mm}$ (Fig. 1), whose position is determined by considering the desired gear ratio. In this case, one of the conditions of a correct mesh is that the measurements of the pitch on the ellipse pitch must be kept constant. The geometric separation of the pitch ellipse into 24 identical sections is mathematically much more difficult than in the case with the standard gear pitch circles.

The development of this gear is analyzed in detail in the literature $[5,7,9]$. The gears for a given variable transmission have been proposed as elliptical - eccentrically placed (Fig. 2).

The conventional gearing involute starts from the base circle, in which case it is the base of the evolute of the ellipse. The evolutes of the left and right sides of the teeth are not 


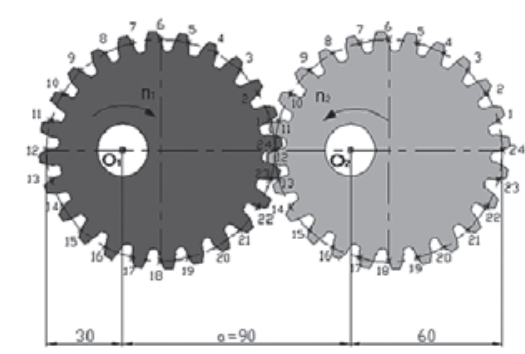

Fig. 2. Designed elliptical gear

Rys. 2. Zaprojektowane eliptyczne koła zębate

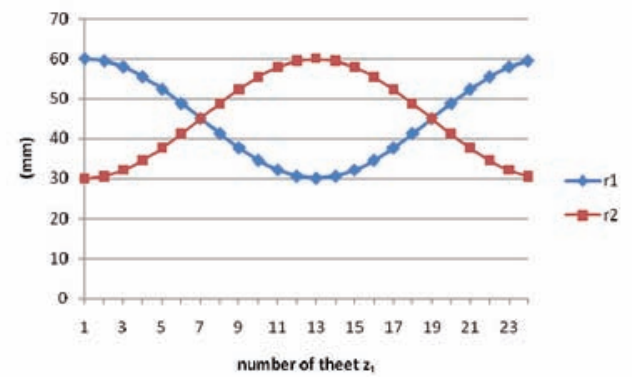

Fig. 3. Radius of mesh points of gear

Rys. 3. Promienie punktów zazębienia koła

the same. Each of the twelve teeth is different; the next twelve teeth of the same wheel are the same. The sides curve is the involute, and is different for active and passive side of the tooth; the teeth are asymmetrical. The gearing consists of two identical gears. The geometric model of the proposed gear is shown in Fig. 2.

\section{Kinematic Properties of Eccentric Elliptical Gearing}

In pursuit of kinematic ratios of the proposed gearings we take into account the right mesh conditions. Kinematic conditions were processed for a gear 1 (the center of rotation at point $\mathrm{O}_{1}$ ) and the gear 2 (with the center of rotation at point $\mathrm{O}_{2}$ ). The two gears are shown in a kinematic dependence on the graph (on the horizontal axis of the wheel teeth first).

Figure 3 shows the teeth radii of the gear points 1 and 2 for a pair of teeth, depending on the temporary position of teeth in respect to the center of rotation. It is also defined in Table 1.

Fig. 4 shows a course of the continuously changing gear ratio in one mesh generated by the elliptical gear, which continuously varies in the range from $u=0.5$ through $u=1.0$ until $\mathrm{u}=2.0$ and back. Thus the gear ratio changes over the time of one revolution. A gear ratio value that is less than 1.0 means that this is an overdrive, and a gear ratio value greater than 1.0 means a speed reduction.

Gear ratio of the designed eccentric elliptical gears depends on the angle of rotation $\varphi$ of the drive wheel (Fig. 5). The gear ratio in the designed eccentric elliptical gears is a function of the angle of rotation (Fig. 6).

The angular velocity of the drive wheel gear and the driven wheel gear is constant for standard spur gears. For the designed

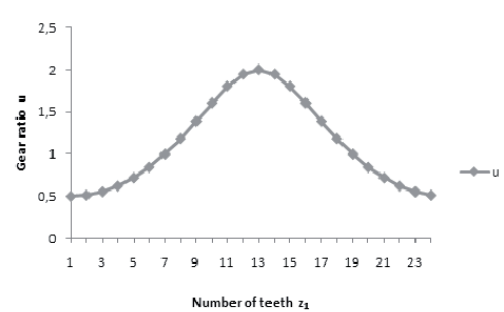

Fig. 4. Continously variable gear ratio

Rys. 4. Przełożenia przekładni bezstopniowej

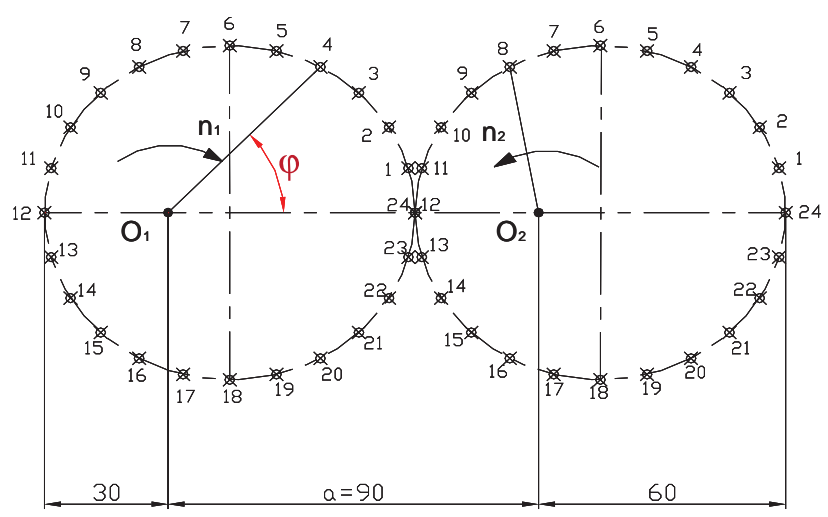

Fig. 5. Designed elliptical gear - definition of angle of rotation Rys. 5. Eliptyczne koła zębate - określenie kąta obrotu

elliptical gearing with the variable transmission, the angular velocity of the driven wheel is not constant but changes according to the continuously changing gear ratio. This is shown in Fig. 7 , for the angular velocity is of the drive wheel $\left(\omega_{1}=100 \mathrm{~s}^{-1}\right)$ and the driven elliptical wheel $\left(\omega_{2 \mathrm{i}}\right)$. The variation of angular velocity is also demonstrated in Table 1.

Table 1. Radius of mesh points of gear and gear ratio Tabela 1. Promienie punktów zazębienia koła i wartości przełożenia

\begin{tabular}{|r|r|r|r|r|}
\hline \multirow{2}{*}{$\begin{array}{c}\text { Meshing } \\
\text { (Fig. } 2)\end{array}$} & \multicolumn{2}{|c|}{ Radius of mesh points } & $\begin{array}{c}\text { Gear ratio } \\
\mathrm{u}_{\mathrm{i}}=\mathrm{r}_{2 \mathrm{j}} / \mathrm{r}_{1-\mathrm{i}}\end{array}$ & $\begin{array}{r}\omega_{2 \mathrm{i}}=\omega_{1} / \mathrm{u}_{\mathrm{i}} \\
\omega_{1}=100\left(\mathrm{~s}^{-1}\right)\end{array}$ \\
\hline $24-12$ & 60.000 & 30.000 & $\mathbf{0 . 5 0 0}$ & 200.000 \\
\hline $1-11$ & 59.459 & 30.541 & 0.514 & 194.704 \\
\hline $2-10$ & 57.892 & 32.108 & 0.555 & 180.310 \\
\hline $3-9$ & 55.450 & 34.550 & 0.623 & 160.514 \\
\hline $4-8$ & 52.337 & 37.663 & 0.720 & 138.966 \\
\hline $5-7$ & 48.779 & 41.221 & 0.845 & 118.343 \\
\hline $6-6$ & 45.000 & 45.000 & $\mathbf{1 . 0 0 0}$ & 100.000 \\
\hline $7-5$ & 41.221 & 48.779 & 1.183 & 84.09 \\
\hline $8-4$ & 37.663 & 52.337 & 1.390 & 71.63 \\
\hline $9-3$ & 34.550 & 55.450 & 1.605 & 62.313 \\
\hline $10-2$ & 32.108 & 57.892 & 1.803 & 55.463 \\
\hline $12-1$ & 30.541 & 59.459 & 1.947 & 51.366 \\
\hline 30.000 & 60.000 & $\mathbf{2 . 0 0 0}$ & 50.000 \\
\hline
\end{tabular}




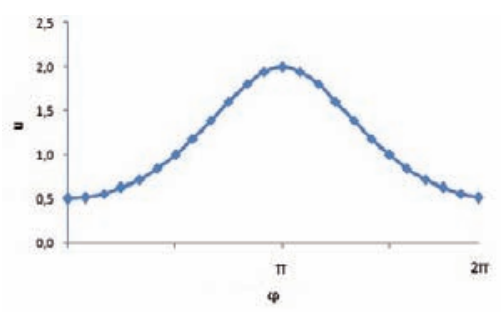

Fig. 6. Changing the gear ratio - function of angle of rotation Rys. 6. Ciągła zmiana przełożenia w funkcji kąta obrotu

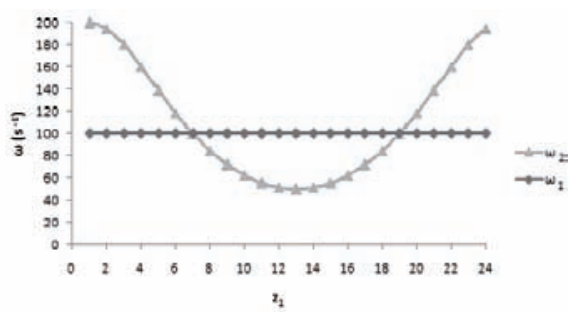

Fig. 7. Angular velocity

Rys. 7. Prędkość kątowa

\section{Manufacturing of Eccentric Elliptical Gearing}

Selecting the optimum mode of production was limited by conditions, such as the number of units produced (only one pair of gears was produced), production should be ensured by technology commonly available in the area and without any expensive products and the costs of production preparation should be as small as possible.

Technical preparation stage of production was secured by a company, which specializes in the development and distribution of CAM systems and NC programming automation and CNC machines.

Based on the conditions, the NC EDM machine was chosen for cutting (the wire cutter) of the EIR 005 B type with the RS-ER5 control system. This machine allows creation of the designed gears and ensures the estimated necessary accuracy of $0.01 \mathrm{~mm}$ and roughness of Ra $1.6 \mu \mathrm{m}$. The basic problem was to generate the NC code for the complex shape gear. This code does not allow a general approach when creating $\mathrm{NC}$ programs for gears, describing the shape of one tooth, which is repeated by the required number of teeth. Other than that it is based on creating the postprocessor (Compiler) for the machine in the CAM2000 system, which is designed to automate the programming of $\mathrm{NC}$ machines. The postprocessor for EDM cutting EIR005B machine with the control system RS-ER5. Its task was to automatically generate the NC code for the designed shape gears. In this way it is possible within a few minutes to develop easily the $\mathrm{NC}$ program for any required profile shape.

For the production of the elliptical gear may be used application of method of powder metallurgy. Powder metallurgy products are currently named as the "economically efficient" products because of their price compared to parts produced for example by material removal operation can be up to $25-50 \%$ lower. Powder metallurgy is characteristic of the use of the material up to $95 \%$ in the manufacture of of the "net-shape" components with no cost to tool machine. Powder metallurgy is one of non-waste technology, and has the character of a closed cycle. Its output is already a finished product ready for installation. It is characterized by up to $50 \%$ energy savings and up to $75 \%$ saving on product mass. This method is suitable for mass- and large-scale production.

\section{Conclusions}

The main objective of this paper was to compare the parameters of the designed elliptical gearing with the parameters of the standard spur gear with constant gear transmission.

Gears for specified gearing with time - change of gear ratio was to be designed as elliptical. The elliptical gear was designed using the AutoCAD software. This gear was the basis for making the gear-box designed for the specified parameters.

\section{Acknowledgment}

This paper was written within the framework of Grant Project VEGA: „1/0688/12 - Research and application of universal regulation system in order to master the Source of mechanical systems excitation".

\section{Bibliography}

1. Bair B.-W., Computerized tooth profile generation of elliptical gears manufactured by shaper cutters, „Journal of Materials Processing Technology“, Vol. 122, Issues 2-3, 2002, 139-147, DOI: 10.1016/S0924-0136(01)01242-0.

2. Brosz M., Bucha J., Míšaný J., Bošanský M., Possibility of using dynamic analysis in the gears desig, „Proceedings: $8^{\text {th }}$ International Symposium about Machine and Industrial Design in Mechanical Engineering". Balatonfüred, Hungary, 12-15 June 2014, University of Novi Sad, 2014, 177-180.

3. Czech P., Wojnar G., Warczek J., Diagnozowanie uszkodzeń wtryskiwaczy w silnikach spalinowych pojazdów przy użyciu analizy bispektrum i radialnych sieci neuronowych, „Logistyka“ No. 3, 2014, 1181-1187.

4. Femandez del Rincon A., Viadero F., et al, A model for the study of meshing stiffness in spur gear transmissions, „Mechanism and Machine Theory“. Vol. 61, 2013, 30-58, DOI: 10.1016/j.mechmachtheory.2012.10.008.

5. Medvecká-Beňová S., Vojtková J., Aplication of asymetric profile in gearing in gearings with eccentric gears, "Zeszyty Naukowe Politechniki Śląskiej“. Vol. 85, No. 1925, 2014, 89-93.

6. Medvecká-Beňová S., Vojtková J., Tooth deformation transfer with variable gear ratio. "Transactions of the Universities of Košice", 2/2011, 73-76.

7. Neupauerová S., Tomagová M., Vojtková J., Ozubený prevod s premenlivým prevodovým pomerom - vytvorenie modelu na základe vyrobeného súkolesia, „46. Medzinárodní konference kateder částí a mechanizmov strojů", Liberec, 2005.

8. Sapieta M., Dekýš V., Pastorek P., Using of activ thermography and lock-in method with ultrasound exication for detection of material defect, ,Zeszyty Naukowe Politechniki Śląskiej“, Vol. 84, no. 1907, 2014, 119-124.

9. Tomagová M., Medvecká-Beňová S., Vojtková J., Ozubený prevod s plynulou, pravidelne sa opakujúcou zmenou prevodového pomeru, "TriboTechnika“, Vol. 3, No. 2, 2010, 36-37. 


\title{
Eliptyczne koła zębate i ich właściwości
}

Streszczenie: Na podstawie specyficznych wymagań została zaprojektowana przekładnia, która podczas jednego obrotu wału napędzającego umożliwia ciągłą zmianę przełożenia. Przekładnię tworzą dwa identyczne koła zębate. Podstawowy kształt koła jest elipsą. Jedno z ognisk jest środkiem obrotu. Koła są zaprojektowane tylko do obracania się w jednym kierunku. Aktywne i pasywne ewolwenty profilów zębów zostały utworzone niezależnie na podstawie odpowiednich fragmentów ewolut eliptycznego koła. Tak zaprojektowane i opracowane przekładnie zębate z kołami eliptycznymi zostały poddane testom - spełniły wszystkie wymogi, które im postawiono. W przypadku przekładni z kołami zębatymi o kształcie eliptycznymi, w przeciwieństwie do przekładni z kołami zębatymi okrągłymi, wartość siły międzyzębnej znacząco zmienia się podczas jednego obrotu koła, co wpływa na różne obciążenie poszczególnych par zębów.

Słowa kluczowe: koło zębate, elipsa, przełożenie w sposób ciągły

\section{Doc. Ing. Silvia Medvecká-Beňová, PhD}

\author{
silvia.medvecka@tuke.sk
}

She works at the Department of Construction, Automotive and Transport Engineering, Faculty of Mechanical Engineering, Technical University of Košice. Her area of interested is focused on the problem of research in the field of gears and gears with a continuous change of speed ratio. She is actively involved in solving a number of tasks, in cooperation with practice.

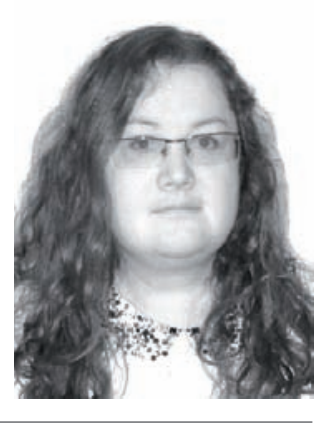

